\title{
Mapping and modelling fractures using ground penetrating radar for ornamental stone assessment and recovery optimization: Two case studies
}

The Mining-Geology-Petroleum Engineering Bulletin UDC: $550.8: 552.1$

DOI: 10.17794/rgn.2017.4.7

Original scientific paper

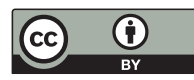

\author{
Mohamed Elkarmoty'; Camilla Colla ${ }^{2}$; Elena Gabrielli; Sara Kasmaeeyazdi+; Francesco Tinti5; \\ Stefano Bonduà ${ }^{6}$; Roberto Bruno ${ }^{7}$ \\ Department of Civil, Chemical, Environmental and Materials Engineering, University of Bologna, via Terracini 28,40131 Bologna, Italy \\ ${ }^{1}$ PhD Student; ${ }^{2}$ Adjunct Professor; ${ }^{3}$ Teaching Tutor; ${ }^{4}$ Research Fellow; ${ }^{5}$ Junior Assistant Professor; ${ }^{6}$ Assistant Professor; ${ }^{7}$ Associate Professor
}

\begin{abstract}
Rock mass is typically characterized by inherent fractures that cause natural blocks of rocks. Unplanned cutting of stone deposits in quarries may lead to over-producing waste (rock debris) or extracting unfit (fractured) stone blocks. This paper presents two case studies through the use of low and high frequency Ground Penetrating Radar (GPR) antennas to detect fractures in two benches of a quarry. In the first case study, a high frequency GPR antenna was used aiming to: (i) compare the GPR results with a map of the out-cropping fracture intensity in the bench surface, developed using the data of the GPR survey marks and interpolated by the Ordinary Kriging technique, and (ii) present how sub-vertical fractures can be numerically modelled in three dimensions from the GPR results. The second case study was focused on using a low frequency antenna to detect large aperture size of fracture surfaces as deep as possible in order to evaluate a deposit stratum before quarrying. This could be done through studying the reflections from a $3 \mathrm{D}$ cross-sectional GPR model and a $3 \mathrm{D}$ transparent GPR model. In the discussion section, an exploitation planning approach, based on modelling fractures as $3 \mathrm{D}$ surfaces, is theoretically and graphically proposed to optimize the stone production recovery. The two case studies showed that GPR is a successful tool for the assessment of ornamental stone deposits and a promising tool for recovery optimization.
\end{abstract}

\section{Keywords}

Ground Penetrating Radar, fracture modelling, ornamental stones, quarrying planning.

\section{Introduction}

Ornamental stones are raw materials with potential economic value that are used in various applications for construction or prestigious purposes (Ashmole and Motloung, 2008). Commercially, a leading factor that gives a profitable value to the stones is the block size, since small sizes of the extracted blocks limit the dimensions required for processing the stone pieces, and consequently a narrow range of applications will be available. Practically, most quarrying operators consider the extracted stones sizes less than the required commercial block size as waste. The block size is a function of the weight and both of them are important for the safety issues of transporting, handling, and processing of blocks (Mosch et al, 2011). The standard dimensions range of commercial block sizes is between $2.0 \mathrm{~m}$ x $1.0 \mathrm{~m}$ x 0.5 $\mathrm{m}$ and $3.0 \mathrm{~m} \times 2.0 \mathrm{~m} \times 1.0 \mathrm{~m}$ (Report of United Nations, 1976).

Rock mass fractures control the feasible exploitation and stability of benches. Fractures provide natural rock-

Corresponding author: Mohamed Elkarmoty

mohamed.elkarmoty2@unibo.it break surfaces which consequently form natural rock blocks that cause production waste during exploitation. These blocks are also named as in-situ blocks and were defined as the resulting blocks from the intersection of discontinuity sets with different characteristics of spacing and orientation (Lu and Latham, 1999). The size of the in-situ block is mainly controlled by the spacing and number of discontinuities (International Society of Rock Mechanics [ISRM], 1979). The profitability of an ornamental stone quarry can be increased by the reduction of waste and extracting a fit commercial block size of stones. A fit block of ornamental stones can be defined as an extracted block without surfaces of fractures that may lead to the loss of the block during the handling or processing phases. Fracture characterization plays an important role in maximizing the production. This can be done through a sustainable process that consists of (i) in situ detection of rock mass fractures, (ii) three dimensional imaging or modelling of fractures, and (iii) exploitation planning based on the fracture's model.

In-situ detection methods of rock mass fractures are varied and the use of a method is governed by the topography of the site, the required accuracy, the cost budget, and the application objective. Topography may cause 


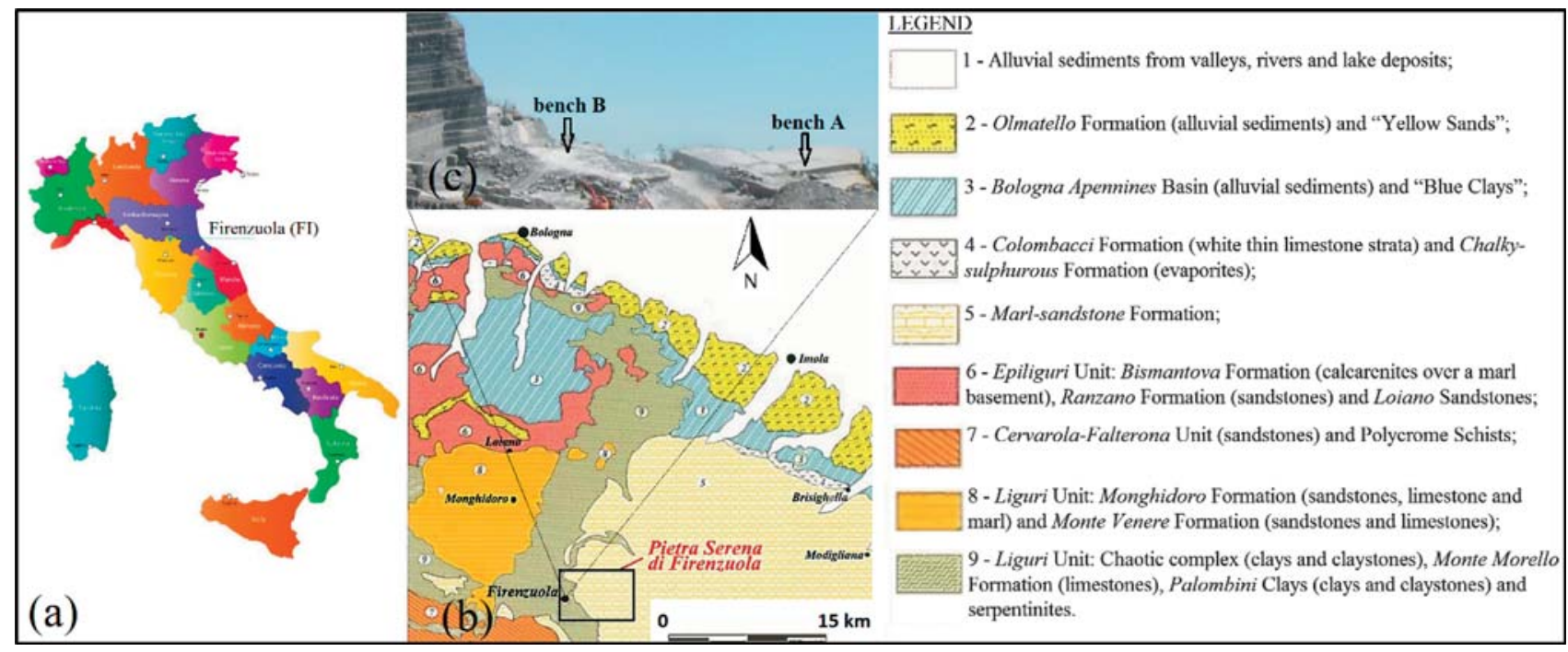

Figure 1: (a) The location of Firenzuola city in Italy, modified from (http://www.italythisway.com/regions/map-of-italy.php).

(b) Lithologic map of the eastern portion of Tosco-Emilian Apennines. The mining area of "Pietra Serena di Firenzuola" is highlighted by a black rectangle, modified from (Bargossi et al., 20o8). The legend was translated to English by the authors. (c) A panoramic view of the quarry referring to the location of the two benches being studied is presented.

difficulty in accessibility to the site, moreover, some fracture detection methods depend on the transportation of heavy machines such as core log analysis (e.g. Annavarapu et al., 2012; Dezayes et al., 2000), borehole radar (e.g. Haeni et al., 2002; Serzu et al., 2004), and borehole tele-viewer (e.g. Dorn et al., 2013; Lau et al., 1987). Recent remote fracture detection methods could solve the accessibility problem, which is significant for applications of fracture detection to landslides and rock slope stability analysis. This category of methods is based on capturing a three dimensional detailed image of a rock mass surface. This image is then stochastically analysed to model the fracture's behaviour. As examples for this category, there are laser scanning (e.g. Ferrero et al., 2009; Olariu et al., 2008; Slob et al., 2007) and photogrammetry methods (e.g. Lato and Vöge, 2012; Vasuki et al., 2014). Non-destructive surface-contact methods are, for example, Ground Penetrating Radar GPR (e.g. Seren and Acikgoz, 2012; Zajc et al., 2014) and seismic profiling methods (e.g. Mineo et al., 2015; Zou and Wu, 2001). A more detailed survey of fracture detection methods can be found in (Elkarmoty et al., 2017a).

Minimizing waste production caused by the presence of natural fractures requires a sustainable non-destructive data acquisition tool. Boring the rock mass of an ornamental stone deposit, for detecting fractures, can be considered as adding a discontinuity for the rock mass, particularly in applications in which the final goal is to maximize the recovery ratio. The recovery ratio is alternatively described as the coefficient of utilization (Galić et al., 2011; Vidić et al., 2012). The diameter of a borehole is relatively much larger than the common aperture size of a fracture surface. Consequently, a borehole may partially affect the scheduled cutting process and the product from the surrounding rock mass. Accurate fracture imaging is required not only in the surface of a rock mass but in the entire body as well. Identification of the three-dimensional extension, orientation, and shape of a fracture surface inside the rock mass is the key point.

In this research, the authors have preferred to use the GPR method, since it is a fast and non-invasive method to detect subsurface fractures. GPR has been trusted to detect subsurface fractures in many applications performed in quarries (e.g. Botelho and Mufti, 1998; Kadioglu, 2008; Luodes and Sutinen, 2011; Mysaiah et al., 2011; Pipan et al., 2000). GPR is a geophysical method based on the transmission of electromagnetic waves in a medium and receiving reflected waves from the subsurface anomalies such as fractures, joints, stratification, etc. Reflections are recorded in a radargram at a double reflective time scale that indicates the subsurface location of reflections. A double reflective time can be transformed into a depth, when a representative dielectric constant of the medium or the average propagation velocity is known. In rock mass, accurate estimation of the bulk representative dielectric constant or propagation velocity is a significant parameter to convert the measured travelling time of reflections into true subsurface depth (Elkarmoty et al., 2017b). The frequency of the electromagnetic waves affects the resolution of the data. Low frequency antennas provide a large penetration depth but with limitation to resolution whilst high frequency antennas provide a more detailed subsurface image but with limitation to penetration depth. Further theoretical basis of the GPR method can be found in (Daniels, 2004; Reynolds, 2011).

In this paper, an application of the GPR method is presented: fractures are detected and modelled, in two different benches, bench $A$ and bench $B$ (see Figure 1), of a sandstone quarry. These two benches were consid- 


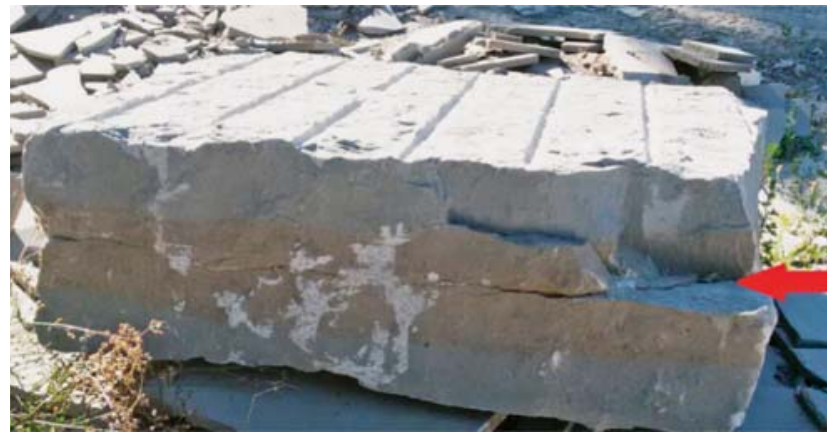

Figure 2: An unfit extracted stone block considered as waste because of a fracture surface indicated on this figure by a red arrow (Elkarmoty et al., 2016)

ered by the quarry technical managers as non-mineable due to the high intensity of fractures that lead to the unfit extraction of stone blocks (see Figure 2). The quarry of the case study is located in Tosco-Emilian Apennines, near the village of Firenzuola, a Metropolitan city of Florence, Italy. The sandstone of this region is almost characterized by a grey colour, with a fine grained compacted structure. There are various uses for this kind of stone. It has always been considered ideal for renovation work, prestigious interior and exterior residential work, commercial buildings with a minimalist style or large modern architectural works. In addition, this stone has been used in furnishings and outdoor works, landscaping, museums, sculptures and artistic restoration work (La Borghigiana Srl Website, 2017). The sandstones of Firenzuola are clastic sedimentary rocks and belong to the Marnoso-arenacea formation (marl and sandstone) (see Figure 1). The sandstones extracted at Firenzuola are also known as "Pietra Serena di Firenzuola"; this name is well-known in the historical heritage of Italy since many monuments were made of this stone, especially in the Tuscany Region (Bargossi et al., 2004). The strata of this formation are steeply dipped, and so the quarrying process is going on a dip with the deposition in order to quarry large blocks, causing steep surfaces of benches in the quarries (Coli et al., 2012).

\section{Case study 1 - bench A}

\subsection{Objective and bench characteristics}

The surface of the bench chosen for survey is flat, which is suitable for the use of GPR. This bench is characterized by outcropping sub-vertical fractures in the bench surface. From the outcropping fractures in the bench surface, it was observed that the fractures propagate in the bench surface in curved irregular paths, not in a straight line (see Figure 3). Some of these fractures crop out in the bench face as well. The quarrying, in this bench, was stopped where the outcropping fracture intensity exceeded the threshold. The bench face was divided into a commercial greyish sandstone deposit and an underlying stratum of a blackish sandstone (see Figure 4).

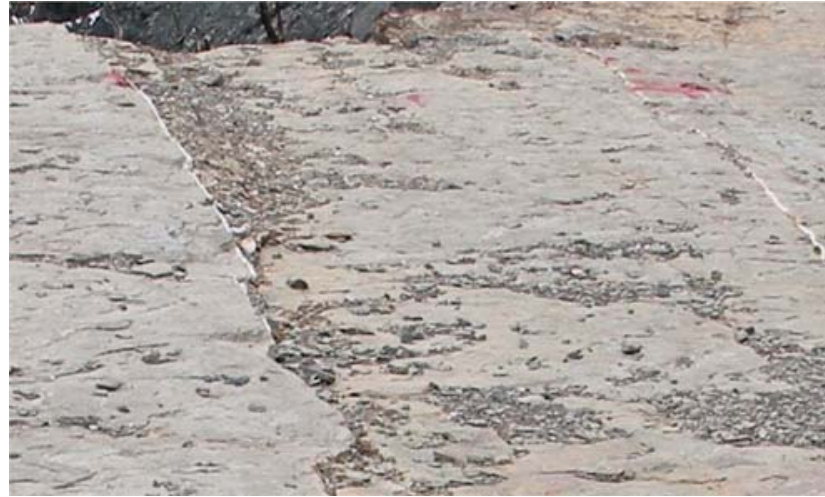

Figure 3: Some outcropping sub-vertical fractures in the bench. The fracture's out-crops are semi-parallel and perpendicular to the bench face.

The objectives of this case study are: (i) to compare the free surface areas of out-cropping fractures in the bench face with the GPR results, (ii) to present how subvertical fracture surfaces can be modelled in three dimensions from a GPR survey numerically to accurately obtain the geometric behaviour of a fracture's surface inside the rock mass body.

\subsection{Methodology}

The GPR unit utilized in this study consists of a SIR operating System-3000, a cart-mounted $400 \mathrm{MHz}$ antenna, and the signal processing software RADAN (all produced by Geophysical Survey Systems GSSI Inc.). In order to obtain a successful GPR survey, survey planning, data collection, and target selection are significant parameters (Bristow and Jol, 2003). A GPR antenna of $400 \mathrm{MHz}$ frequency was selected to have a compromise between good resolution and a reasonable penetration depth. After checking the response of the signal in the rock mass, the geophysical preliminary acquisition parameters could be estimated and entered into the operating system. An area $25.0 \mathrm{~m}$ long (x-axis) and $11.0 \mathrm{~m}$ wide (y-axis) was surveyed through parallel GPR survey lines to the $\mathrm{x}$-axis with a spacing of $1.0 \mathrm{~m}$. The first survey line was $2.0 \mathrm{~m}$ far from the edge of the bench face to allow easy and safe motion of the GPR cart. While moving the GPR cart along a survey line, the surveyor can put a mark on the radargram on the operating system once the cart moves over an outcropping fracture. These marks appear in the X-axis of radargrams and help with the interpretation. In this study, the out-cropping subvertical fractures in the bench face were marked to map the intensity of the out-cropping fractures in the bench surface and to compare the outcropping intensity of fractures with what is hidden in the interior body of the rock mass. The survey lines were designed parallel to the edge of the bench face (see Figure 4), perpendicular to the outcropping sub-vertical fractures to obtain crosssectional reflections from fracture surfaces (CarreonFreyre and Cerca, 2006; Theune et al., 2006). By trac- 
ing the parallel cross-sectional reflections of fracture surfaces, it is possible to numerically model fractures in three dimensions.

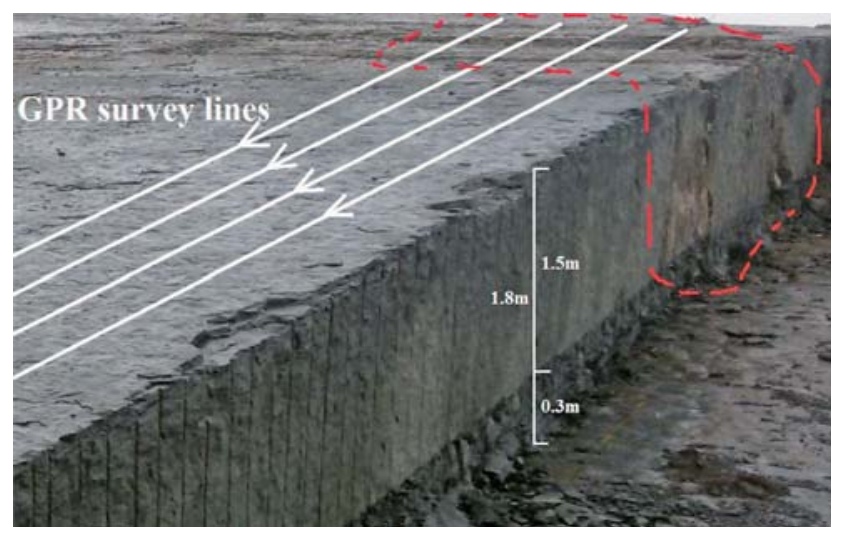

Figure 4: A panoramic view of bench A showing the direction of the GPR survey lines. The red dotted polygon, in the right hand side of this figure, refers to the most fractured outcropping zone. Thin aperture outcropping fractures are not visible in this picture since it was taken on a rainy day. The thickness of the commercial greyish stratum was $1.5 \mathrm{~m}$ whilst an underlying apparent thickness of $0.3 \mathrm{~m}$ was for a blackish sandstone stratum.

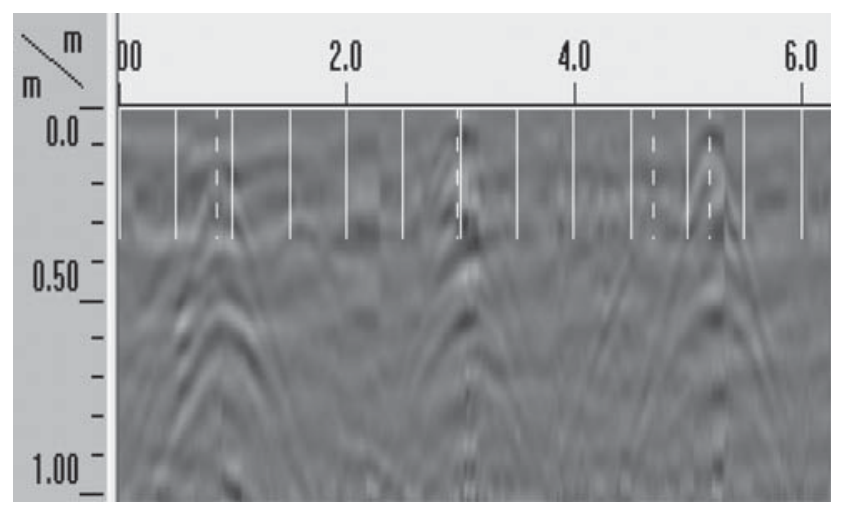

Figure 5: Hyperbolic reflections, due to sub-vertical fractures in the highly fractured zone, detected in a radargram. The dotted vertical lines (marks) indicate a location of a sub-vertical fracture outcrop in the bench surface.

\subsection{Results}

A previous GPR test on the rock mass of the site, performed by the authors, led to estimate a relative dielectric constant value for the medium (Elkarmoty et al., 2017c). A maximum penetration depth of about $2.5 \mathrm{~m}$ was achieved. Standard signal processing functions were applied to the radargrams by RADAN software. Due to the existence of sub-vertical fractures and the conic spread of the electromagnetic waves, hyperbolic reflections typically appear in the radargrams (see Figure 5). A signal processing technique, migration, was used to destruct the hyperbolic signatures and converting them into relatively small successive spots along the fracture trace. Migration allows for the movement of the dipping reflectors to their original position.

The coordinates of each recorded mark, of the outcropping sub-vertical fractures, were picked out from the $\mathrm{x}$-axis of the 12 radargrams. It should be mentioned that some out-cropping sub-vertical fractures were not recorded as marks due to human error, however, the majority of the out-cropping sub-vertical fractures were recorded. The picked marks were graphically represented in such a way that focuses on the intensity of the outcropping fractures from parallel radargrams in the centre of a $1.0 \mathrm{~m}^{2}$ confined surface area (see Figure 6a). The centre of each $1.0 \mathrm{~m}^{2}$ is described by a 3D coordinate of $(\mathrm{x}, \mathrm{y}, \mathrm{z})$, where $\mathrm{z}$ is the number of marks within the 1.0 $\mathrm{m}^{2}$. A data set of coordinates (see Figure 6b) for the tested area was entered in the Surfer ${ }^{\mathrm{TM}}$ software package and then interpolated by the Ordinary Kriging technique, where Kriging is an interpolation method used for generating maps on a grid of spaced data. The interpolation was performed by a variogram that provides a description of how data is spatially dependent (auto-correlated) with distance (Wackernagel, 2003). The semi variogram analysis of data and the model are shown in Figure 7 while the values of the experimental variogram and the parameters of the variogram model are given in Table 1 and Table 2 respectively. The estimation standard deviation map and the resulting contour map of the out-cropping fracture intensity in the tested area are presented in

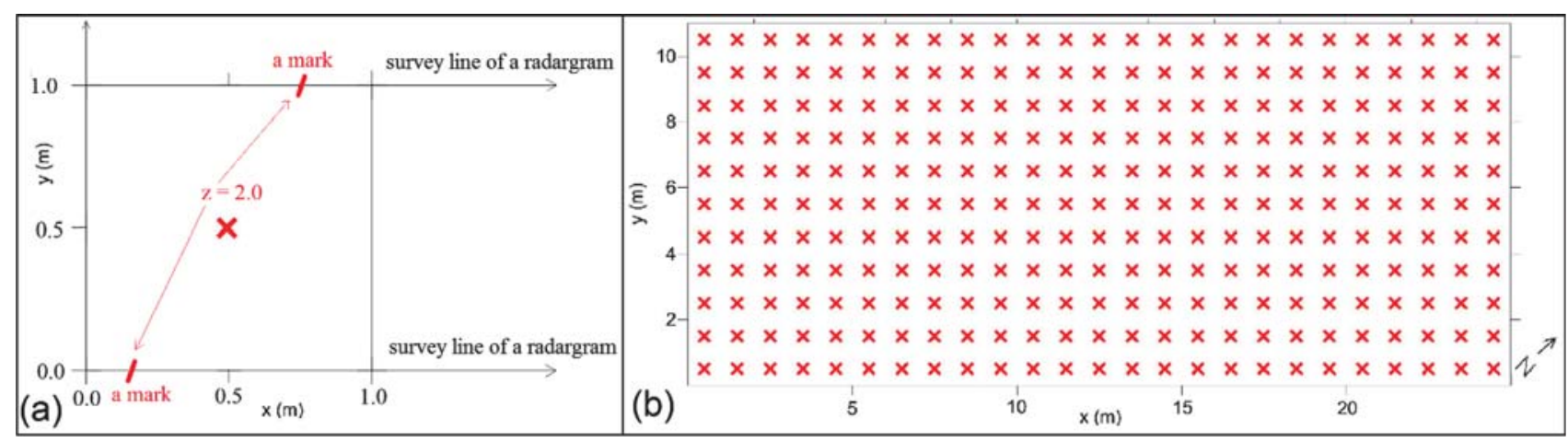

Figure 6: Graphical illustration of how the GPR survey marks of the out-cropping sub-vertical fractures were numerically linked to the centre of a $1.0 \mathrm{~m} 2$ confined surface area (a) and the distribution of the resulting data set (b). The axis $\mathrm{x}(\mathrm{m})$ is the axis parallel to the bench face. 
Figure 8a and Figure 8b respectively. The contour map showed that the west zone is more fractured than the east zone. In particular, the white zone in the contour map is the free zone of out-cropping sub-vertical fractures. This zone may be preliminarily considered as a fresh rock, however what is inside the rock mass body is still unknown. Thus, analysis of the GPR results in the white zones was performed. The results showed that even

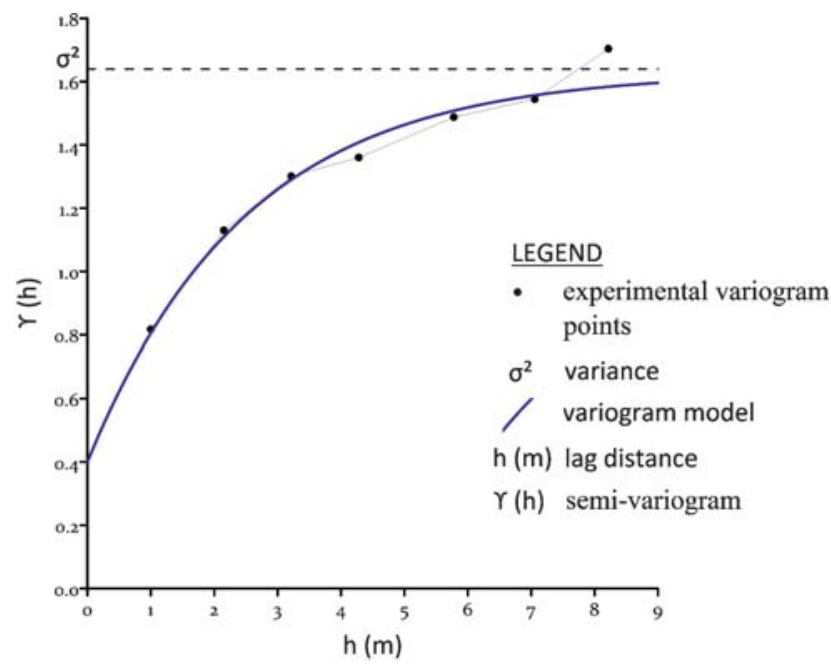

Figure 7: Semi-variogram analysis conducted on the data set. though the white zone has the least out-cropping subvertical fractures, it is also characterized by sub-horizontal fractures inside the rock body (see Figure 8c and Figure 8d).

For the purpose of numerically modelling the fracture surfaces in three dimensions, four successive radargrams with a spacing of $2.0 \mathrm{~m}$ were selected to demonstrate how sub-vertical fractures can be modelled numerically from

Table 1: Values of the experimental variogram.

\begin{tabular}{|l|c|c|}
\hline $\mathrm{h}(\mathrm{m})$ & $\gamma(\mathrm{h})$ & number of pairs \\
\hline 1.00 & 0.82 & 514 \\
\hline 2.15 & 1.13 & 1370 \\
\hline 3.21 & 1.30 & 2444 \\
\hline 4.28 & 1.36 & 1808 \\
\hline 5.78 & 1.49 & 2468 \\
\hline 7.06 & 1.54 & 2598 \\
\hline 8.22 & 1.70 & 2204 \\
\hline
\end{tabular}

Table 2: Parameters of the variogram model

\begin{tabular}{|l|l|l|}
\hline \multicolumn{2}{|l|}{ variogram structure } \\
\hline \multirow{2}{*}{ nugget effect } & \multicolumn{2}{|l|}{ exponential model } \\
\cline { 2 - 3 } & $\mathrm{c}-$ sill & a - range \\
\hline 0.40 & 1.23 & 2.50 \\
\hline
\end{tabular}

Figure 8: A map of the standard deviation of the Kriging estimation (a) with the resulting Kriging contour map of the estimated fracture intensity (b) and comparing the free surface area of out-cropping sub-vertical fractures with the GPR results in two radargrams (c and $\mathrm{d}$ ). (a)
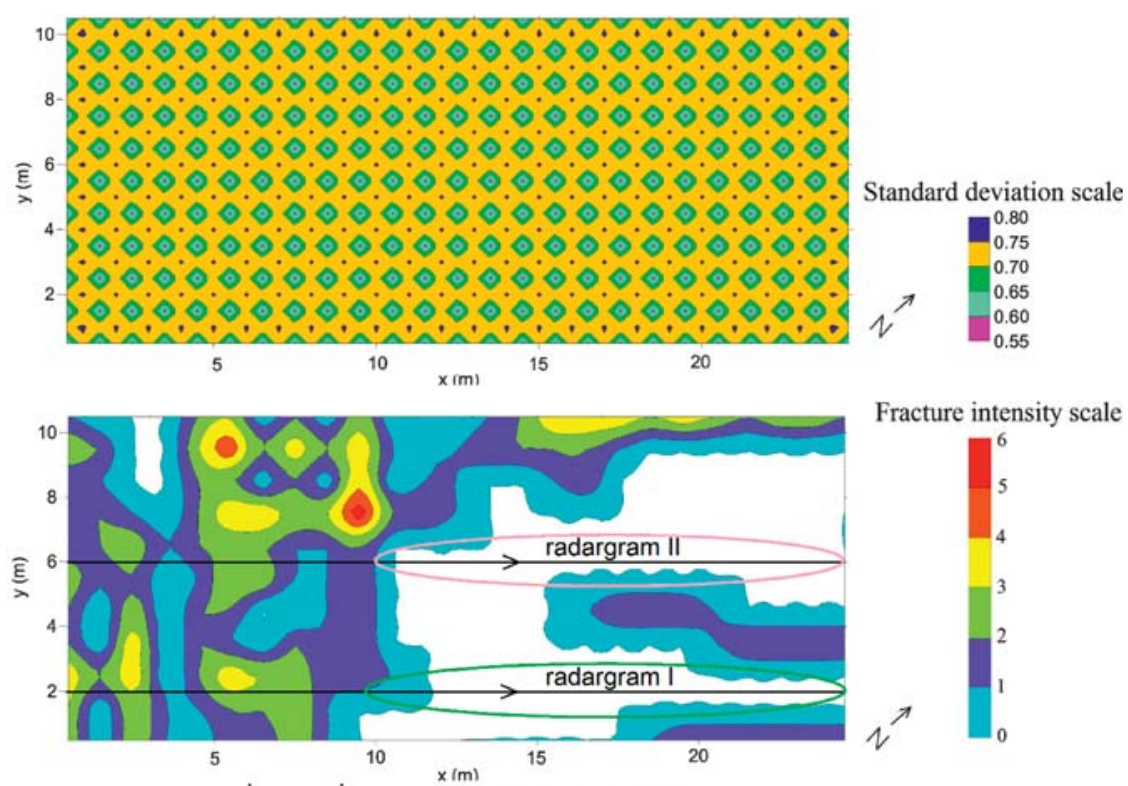

Fracture intensity scale

(c)

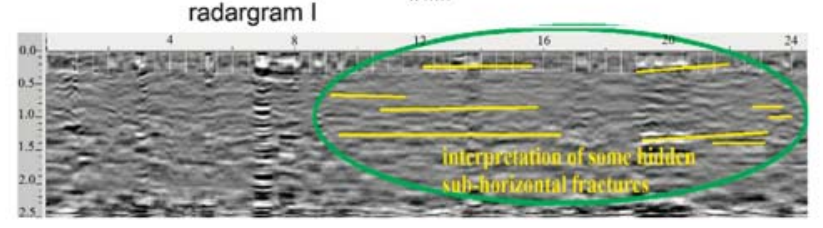

radargram II

(d)

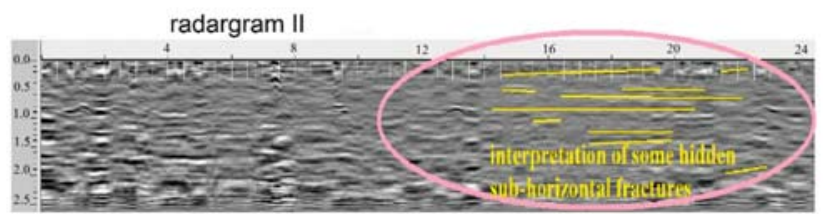




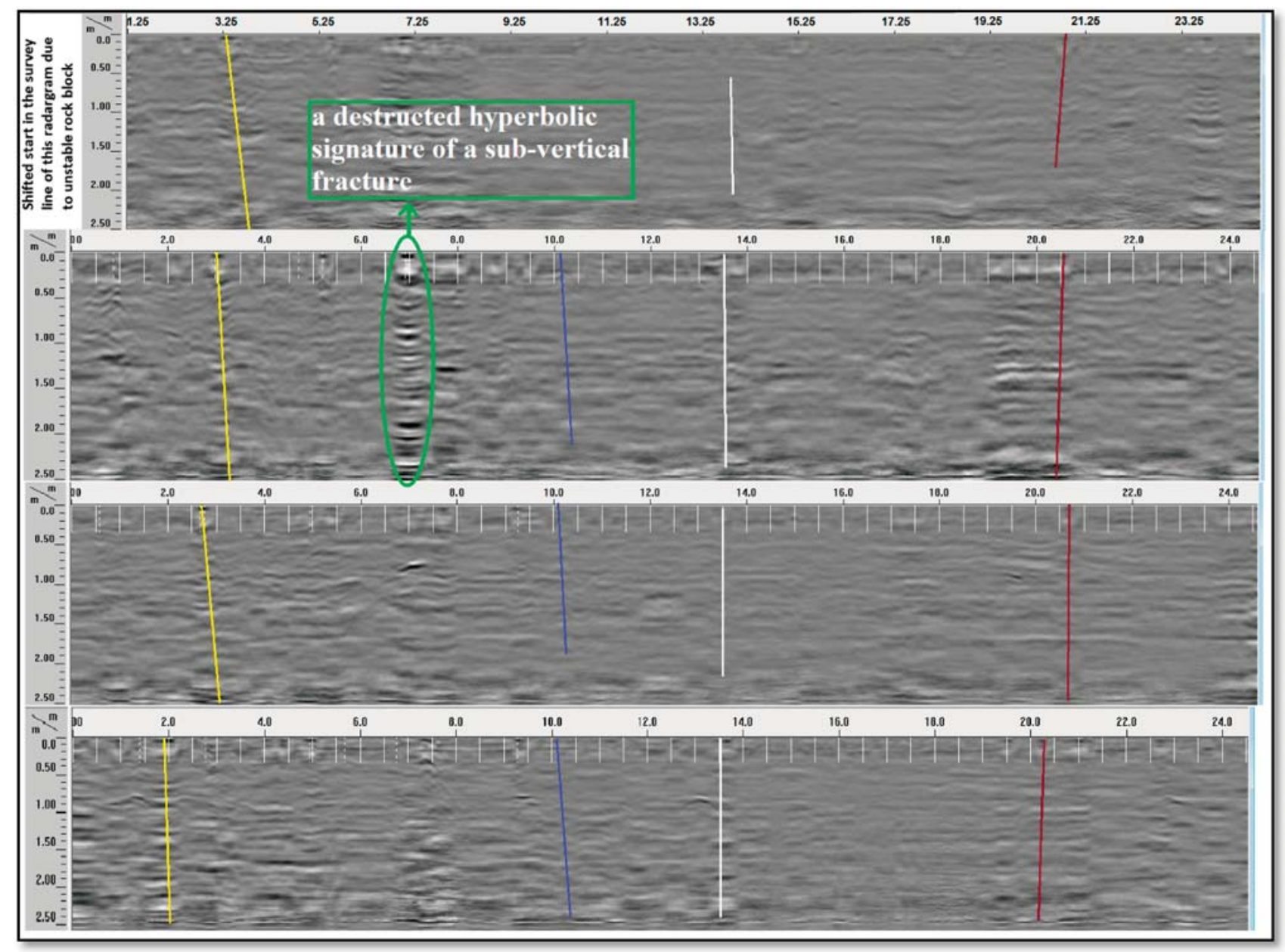

Figure 9: Interpretation of four sub-vertical fracture surfaces from successively ordered radargrams. The uppermost radargram is the one of $2.0 \mathrm{~m}$ far from the bench face. Each fracture surface is interpreted by a single colour. In this figure, not all sub-vertical fracture surfaces are interpreted. The green ellipse refers to a destruction of a hyperbolic signature from a sub-vertical fracture reflection.

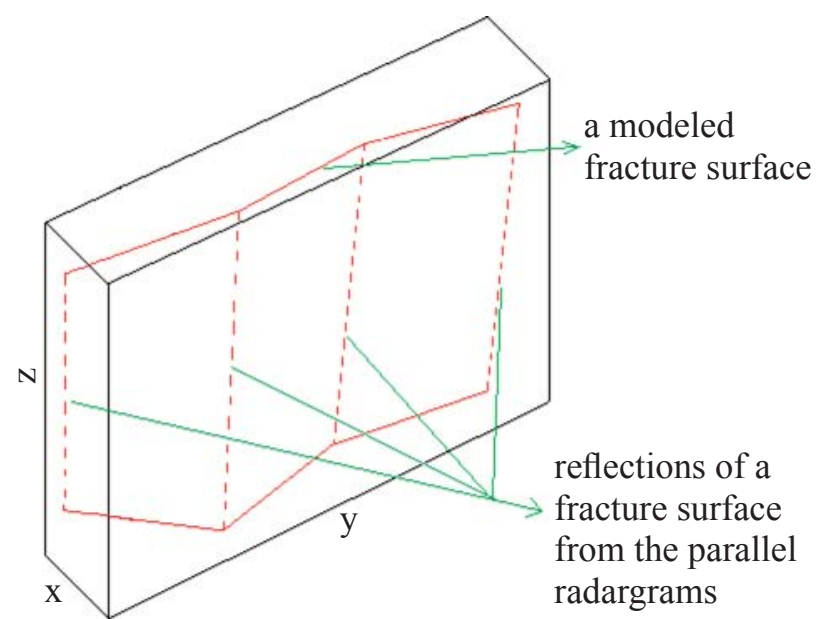

Figure 10: A model for an irregular $3 \mathrm{D}$ fracture surface resulting from tracing the belonging fracture reflections

(dashed lines) in the radargrams. This fracture surface is the model of the fracture reflections presented in the garnet colour on the right hand side of Figure 9. The black rectangle is a simulation of a partial body of the bench and it is used in this figure for better visualization of the fracture surface.

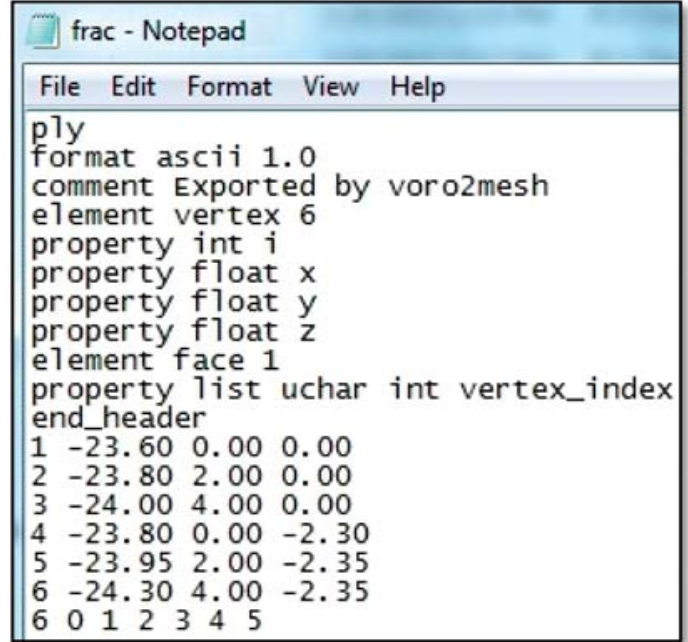

Figure 11: Coding a modelled fracture surface in the (.PLY) format to be entered in ParaView.

GPR results (see Figure 9). The used fracture interpretation technique is based on tracing the reflections of a fracture surface considering the amount of amplitude reflec- 


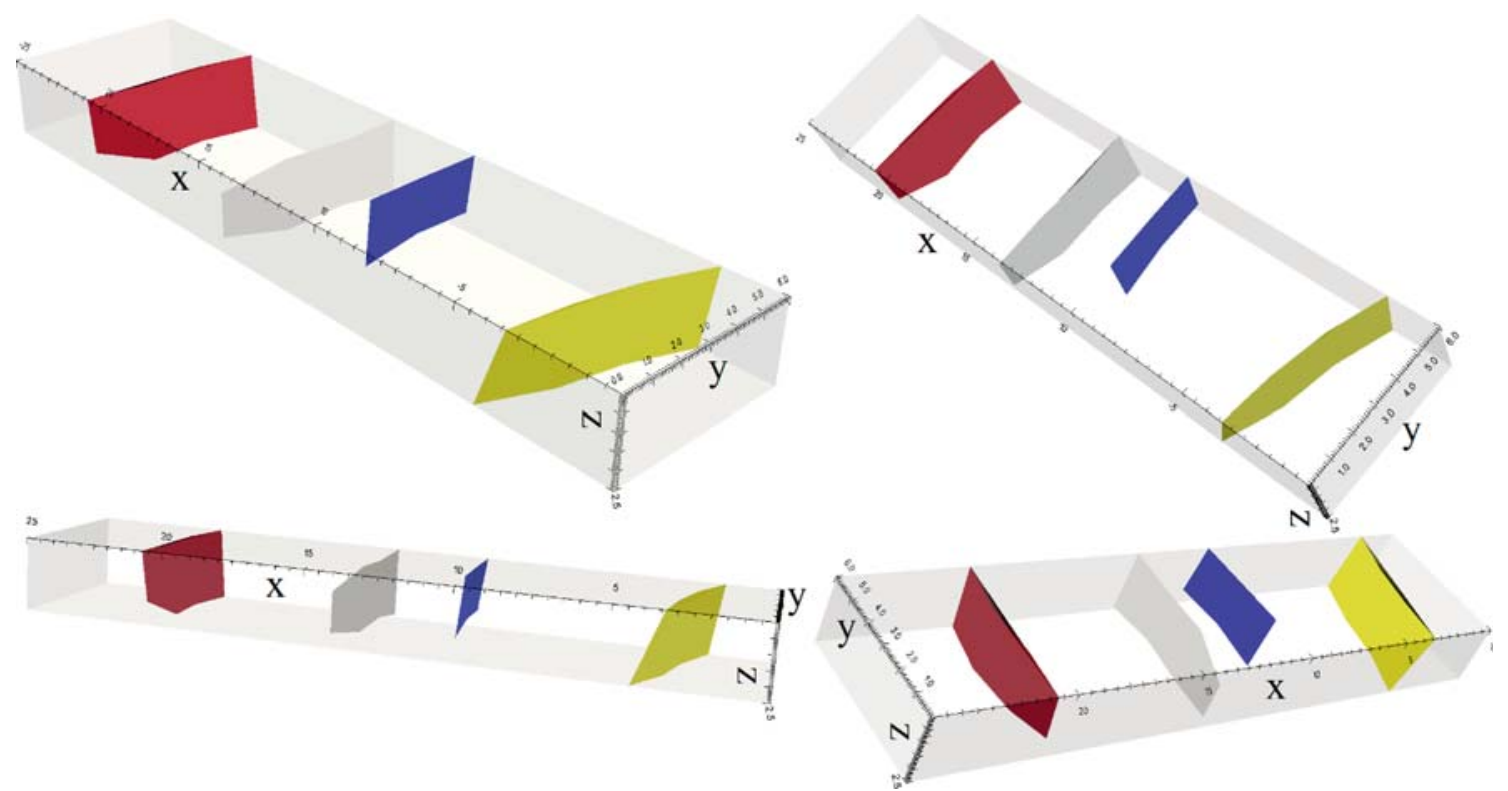

Figure 12: Graphical representation of four modelled fracture surfaces inside the rock body of the bench, visualized in different orientations using ParaView. The colours of the fractures surfaces are the same colours used in the interpretation of fractures in Figure 9.

tions, the location, and the inclination of fracture reflections. The interpretation is performed in such a way to use a specific colour for all fracture reflections belonging to a fracture surface. The interpreted radargrams showed that the degree of inclination of sub-vertical fractures are varied, since some fractures are almost vertical while others are slightly inclined. However, some fractures crop out in the bench surface, the radargrams showed that they do not propagate up to the maximum penetration depth achieved $(2.5 \mathrm{~m})$, such as the blue fracture surface. In contrast, the yellow fracture surface, for example, crops out in the bench surface and propagates in the whole propagation depth. Moreover, a reflection of a sub-vertical fracture could be detected even though the fracture does not crop out in the bench surface, such as the white fracture trace in the top radargram of Figure 9.

Fracture surfaces are typically modelled as planes, however it is preferable to model fractures as irregular curved surfaces as they naturally exist in most cases. A modelled fracture surface by this model is geometrically conditioned by its related detected reflections in the radargrams (see Figure 10).

The extreme coordinates of a fracture's reflections in the radargrams were manually picked and numerically modelled as fracture surfaces by coding the coordinates of the vertices of a fracture surface in a file format (PLY format) that can geometrically describe the shape of the objects in three dimensions (see Figure 11). This allows for better perception of the modelled fractures in the rock mass. Using the coded files (.PLY), the three dimensional behaviour of these modelled fracture surfaces was visualized by a graphical software package ParaView (ParaView Website, 2017) in different orientations as shown in Figure 12.

\section{Case study 2 - bench B}

\subsection{Objective and bench characteristics}

Low frequency GPR antennas can be used for exploring the site geology, such as fractures, and detecting deep buried large objects (Annan, 2003; Davis and Annan, 1989). In a characterization of sandstone (White et al., 2004) and granitic rock (Mysaiah et al., 2011), a $100 \mathrm{MHz}$ GPR antenna was used, achieving a penetration depth of about $16.0 \mathrm{~m}$. Low GPR antenna frequencies of 50 and $100 \mathrm{MHz}$ were used by (Jeannin et al., 2006; Theune et al., 2006) to detect the main discontinuities, in limestone, reaching to penetration depths of about 20.0-30.0 $\mathrm{m}$ and 30.0-40.0 m respectively. However, the same rock type (limestone) is predominant in these two studies, the penetration depth is variable even with the same GPR antenna frequency. The main reasons are the variable status of homogeneity, discontinuity, and saturation inside the rock mass that attenuate the signal and consequently decrease the penetration depth of the signal. The main objective of this case study is to detect large aperture size of fractures at a depth as large as possible by investigation with a low frequency GPR antenna in bench $B$.

The surface of bench $B$ is characterized by large aperture sizes $(2.0-3.0 \mathrm{~cm})$ of out-cropping sub-vertical fractures (see Figure 13a). The strata in this bench are stratified parallel to the bench surface. The bench face is divided mainly into two categories of stones, overburden and a strata or a deposit of commercial quality. Some of these sub-vertical fractures do not noticeably crop out in the tested zone of bench B (see Figure 13b), however they noticeably crop out in close zones of bench $B$ (see 

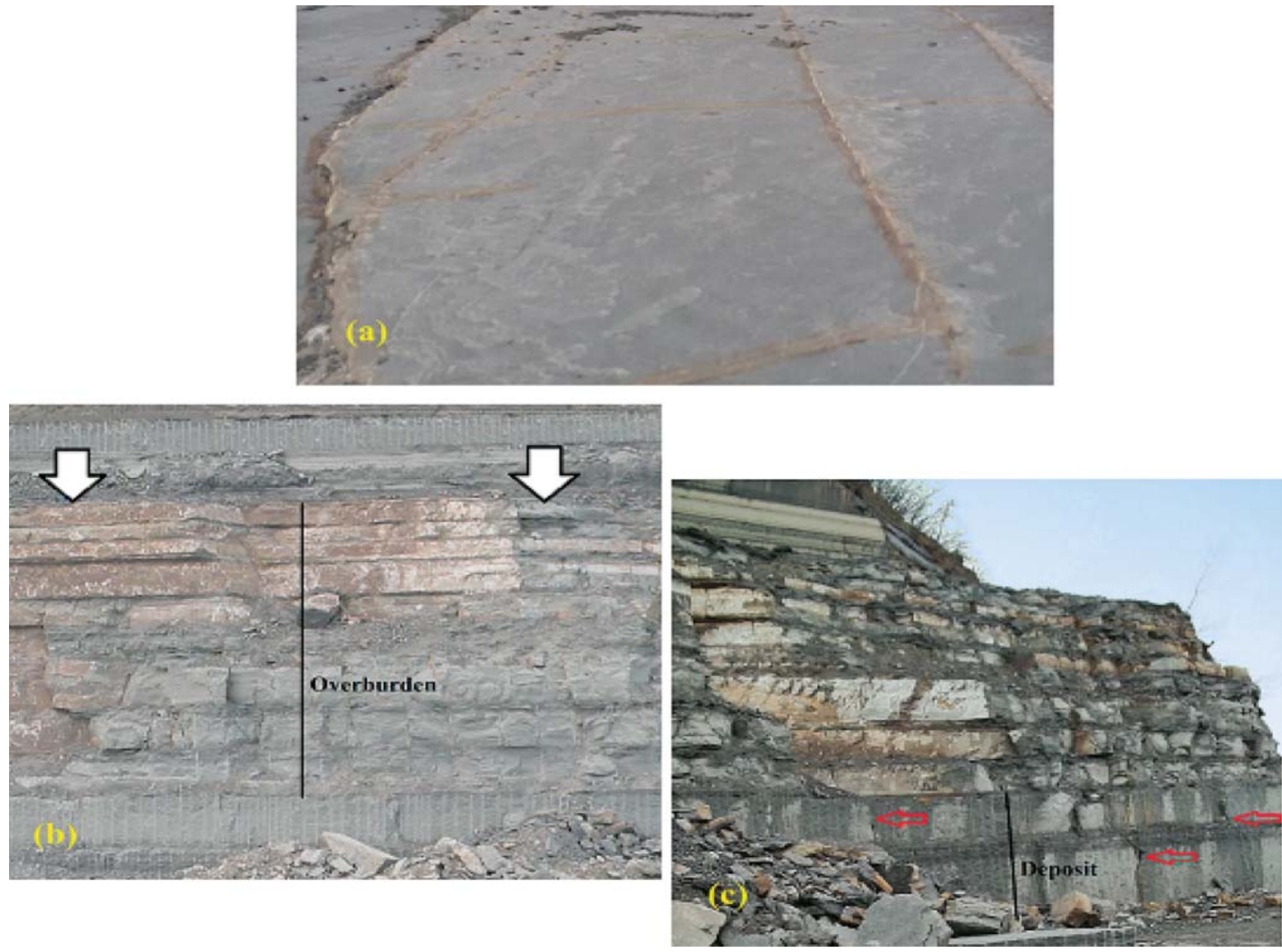

Figure 13:(a) Some sub-vertical fractures, with large aperture sizes, out-crop in the surface of bench B. (b) A front view of the bench face over which the GPR survey was performed, the depth of the overburden is about $6.0 \mathrm{~m}$. The white arrows refer to the longitudinal extreme limits of the GPR survey grid. (c) An extension of the face of bench B from the right hand side of the surveying area, where out-cropping sub-vertical fractures in the commercial quality strata (deposit) are noticeable.

Figure 13c). The overburden is a highly fractured noncommercial quality of sandstones. The bench is characterized by blocky structure behaviour due to the intersections of joints sets. The surface of the bench at the tested area was flat and suitable for the movement of the GPR. The study aims to explore the existence of the main fractures inside the body of the rock mass of bench $B$, particularly in a zone of the good quality stratum (the deposit). Research questions, which this study is concerned with are: i) to what extent the outcropping sub-vertical fractures propagate inside the rock mass and, ii) what is the intensity of the main fractures in the good quality stratum.

\subsection{Methodology}

A three dimensional survey grid over the surface of bench $B$ was planned. The position of the survey grid was selected to be over a deposit horizon, in which there are no noticeable out-cropping large aperture sizes of sub-vertical fractures. In this case, planning a three dimensional GPR survey grid was necessary with the use of a low frequency antenna, to compensate the resolu- tion through GPR data interpolation between the close survey lines. Additionally, the sets of the outcropping main sub-vertical fractures in the surface of the bench was intersected in a semi-orthogonal behaviour, thus, in contrast to the case in bench A, using two orthogonal directions of GPR survey lines in a survey grid was preferred. The dimension of the survey grid is $12.0 \mathrm{~m}$ long (y-axis) and $7.0 \mathrm{~m}$ wide (x-axis), the side of $12.0 \mathrm{~m}$ was parallel to the bench face. The surveying grid started at $8.0 \mathrm{~m}$ far from the edge of the bench face to check the entire existence of fractures. The grid spacing was $1.0 \mathrm{~m}$ long and $1.0 \mathrm{~m}$ wide, leading to 21 radargrams. The GPR unit utilized in this study consists of a SIR operating System-3000, a $70 \mathrm{MHz}$ antenna adapted to a cart, and the signal processing software RADAN (all produced by Geophysical Survey Systems GSSI Inc.).

\subsection{Results}

The 21 raw radargrams were carefully checked in order to determine the required signal processing functions. The same dielectric constant value for the medium 


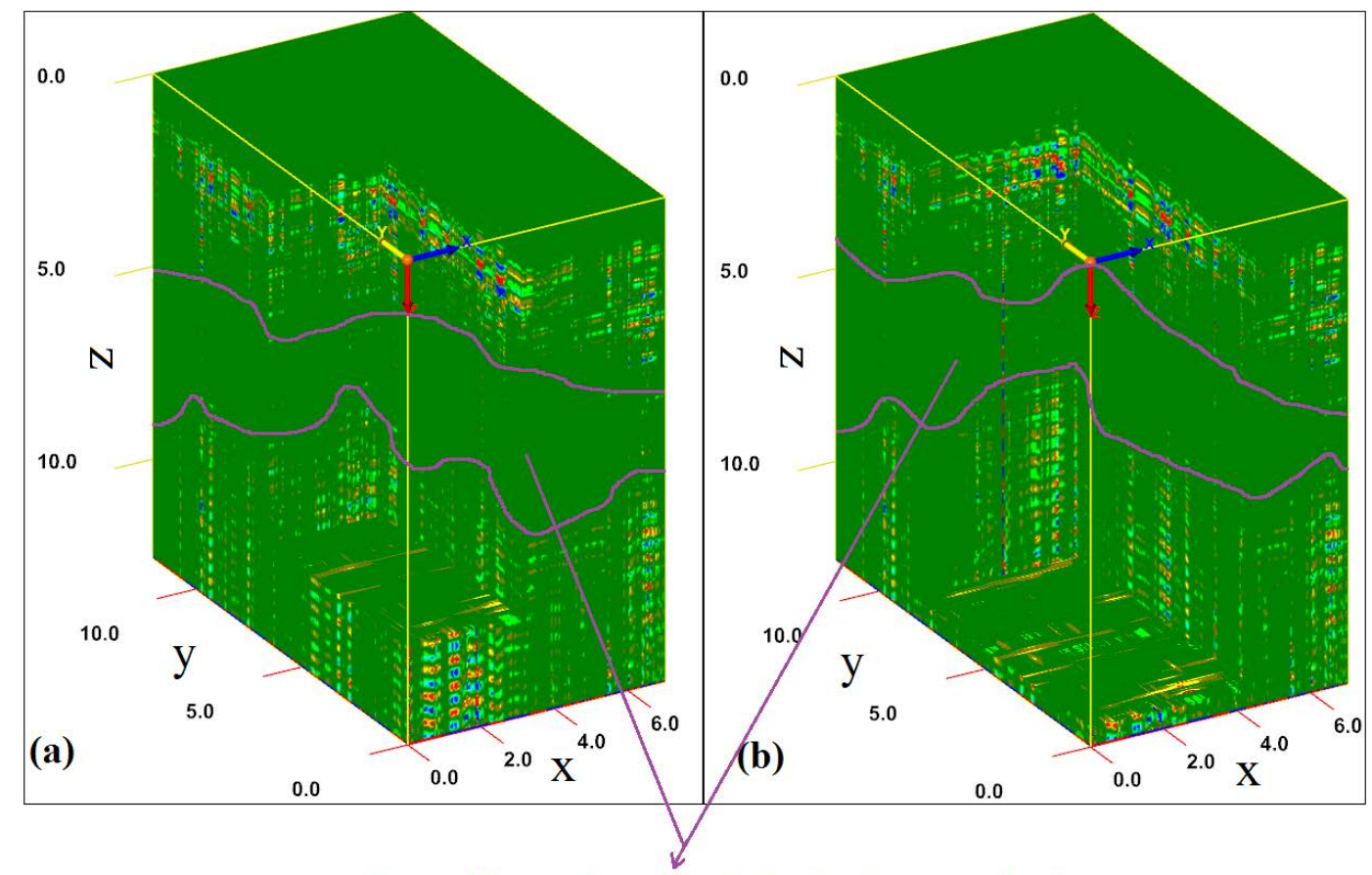

a three-dimensional rock body characterized

by the lowest amount of fracture reflections

Figure 14: Two 3D cross-sections of the GPR cuboid; (a) at $\mathrm{x}=3.0 \mathrm{~m}, \mathrm{y}=6.5 \mathrm{~m}, \mathrm{z}=10.0 \mathrm{~m}$ (b) at $\mathrm{x}=4.5 \mathrm{~m}, \mathrm{y}=8.5 \mathrm{~m}, \mathrm{z}=12.0 \mathrm{~m}$.

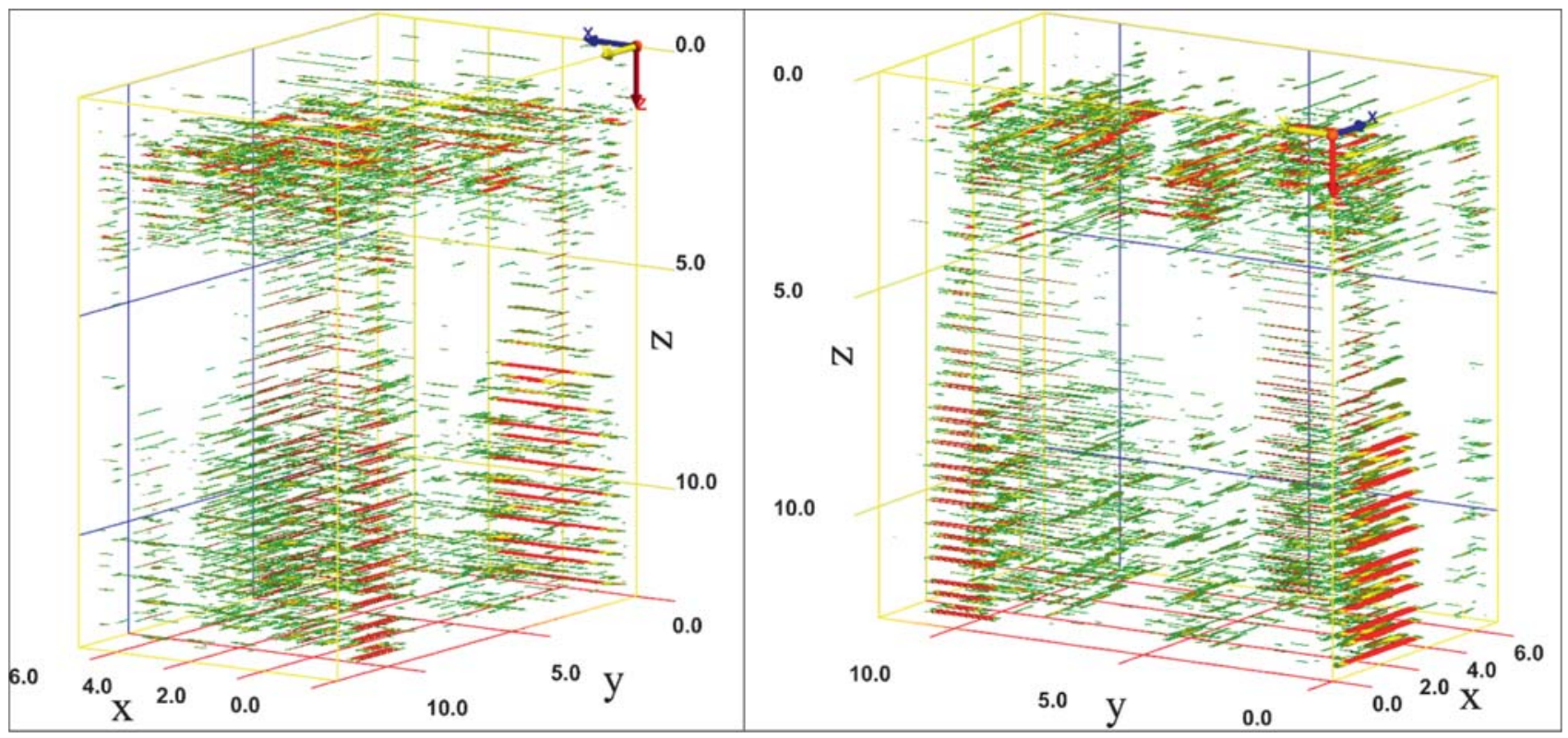

Figure 15: A 3D transparent GPR model visualized from two different orientations.

used in bench $A$ was also used for bench $B$. Even though there are two different benches, the assumption is that the lithological nature of both the benches are almost similar since they are close to each other. Using RADAN software, the reflected data was processed leading to enhancing the signal and clarifying the reflections in the cross-sectional radargrams and a maximum penetration depth of $14.0 \mathrm{~m}$ was obtained.
To explore the entire body of the surveyed rock mass, a three dimensional GPR model was built by the processing software package. The 3D GPR model is based on interpolating the data-free areas between the $2 \mathrm{D}$ radargrams in order to obtain a 3D subsurface image for the whole body of the rock mass. Through exploring the 3D cross-sections of the GPR cuboid (see Figure 14), it was noticed that there is a zone of discontinuous reflec- 
tions of fracture surfaces, particularly in a three-dimensional rock body in the middle of the body of the surveyed rock mass. This zone is located between a depth of about $5.0 \mathrm{~m}$ and $10.0 \mathrm{~m}$. This zone is characterized by the lowest amount of fracture reflections as compared to the whole rock body, however, there are a few reflections of fractures in this zone. Moreover, a transparent 3D GPR data visualisation allowed for a better understanding of the fracture's status inside the whole rock mass body. The 3D transparent GPR model also confirmed the interpretation of the lowest amount of fracture reflections in the three-dimensional zone between about $5.0 \mathrm{~m}$ and $10.0 \mathrm{~m}$ (see Figure 15). By investigating the GPR models, it can also be observed that the rock mass in this bench is characterized by nearly two perpendicular sets of large aperture fractures, one set is perpendicular to the bench face and the other is parallel to the bench face.

\section{Discussion}

In this section, discussion and suggestions for quarrying purposes, obtained from the analysis of results, are presented. Regarding case study 1 , the studied bench is non-mineable due to the high intensity of fractures. However, a general exploitation planning approach, based on the results of modelling fractures as 3D surfaces from GPR results as presented in this case study, is hereby proposed.

Determining the cutting zone of fit blocks in a bench can be optimally carried out after the accurate modelling of fractures. Planning the cutting zone of fit stone blocks can sustainably decrease the amount of waste. This exploitation planning approach could be illustrated in a simple case of a bench with a single set of sub-vertical fractures with large spacing (see Figure 16). If fractures are typically modelled as three dimensional flat planes, there will be a potential risk of wasting material during the cutting operation. While modelling fractures as irregular 3D surfaces as close as possible to reality, like in the case study of bench A, may lead to decreasing waste. The zone of fit stone blocks can be optimally described as an irregular surface area bounded between two borders. The first border is the projection of the lower edge of a modelled fracture surface on the surface of the bench, hence the projection of the lower edge is limited to the required thickness or depth of commercial stone blocks. The second border is supposed to be the intersection of an irregular modelled fracture surface with the bench surface (or outcrop), however an offset tolerance area of some centimetres as a quarrying optimization factor of safety is preferable. Then, an optimization algorithm can be used to find the optimal cutting direction that maximizes the number of extracted fit stone blocks, with the required commercial size, from the zone of fit blocks. This process may be time consuming and mathematically complicated, however it is expected to minimize waste. If such an approach will be done in future research, the main obstacles for applying this method in industry is the possibility of modelling fracture surfaces in large areas in addition to the time consuming matter, however with programming such a model, the time consuming matter can be minimized.

For a case of more than one fracture set (see Figure 17), the quantity of fractures zones increases and, consequently, zones of cutting fit blocks decrease. Therefore, determining the optimum cutting direction becomes more difficult. This case is the most common in nature, that's why developing a quarrying model based on the suggested approach, that deals with all the cases of fracture sets is required to optimize the recovery. Actually, the most dangerous parameter is not the orientations of fractures or number of sets but the spacing between the fractures. The larger the spacing of a fracture set, the larger is the amount of extracted fit blocks. In case of a highly fractured rock mass, with sub-vertical and subhorizontal fractures, most quarrymen currently consider such stone deposit as non-mineable in terms of extracting commercial size fit blocks. However this is partially true, being such stone deposit mineable is sustainably possible in two preliminary conditions. The first is the accurate modelling of fractures whilst the second is the possibility of using a disc sawing machine as a quarrying method which cuts simultaneously in two directions (horizontal and vertical). Consequently, direct extraction of small size blocks may be obtained. Small slabs for paving or flooring can be then released from these small size blocks.

With regard to case study 2, the GPR results point out that a particular three-dimensional rock body of the rock mass, in a depth between about 5.0 to $10.0 \mathrm{~m}$, is less fractured in comparison to the whole body of the rock mass. Actually the absence of fracture reflections in this depth region is expected to be because of two reasons: (i) higher mechanical properties of the rock strata in this depth region, and (ii) the limited resolution of the used antenna. The investigation of these two points is considered as future work. If this stratum has higher mechanical properties in comparison to the other strata, the interpretation of discontinuous extension of fractures may be because of a reduction in the size of fracture aperture that the antenna resolution is unable to detect. A mechanical test for some samples from all the strata existing in this bench is recommended to validate this viewpoint. Using a reasonable higher frequency GPR antenna, that can reach to a penetration depth between $5.0 \mathrm{~m}$ and $10.0 \mathrm{~m}$, to survey this rock mass is recommended for result comparison. Apparently, in the depth range between 5.0 to $10.0 \mathrm{~m}$, there is commercial quality stratum which means that, in comparison to the whole body, some parts in the commercial quality stratum are without large aperture size fractures. Wider areas should be surveyed in order to decide the feasibility of quarrying the whole bench or a part of it. With limitation to the results of the surveyed area, the GPR models showed 


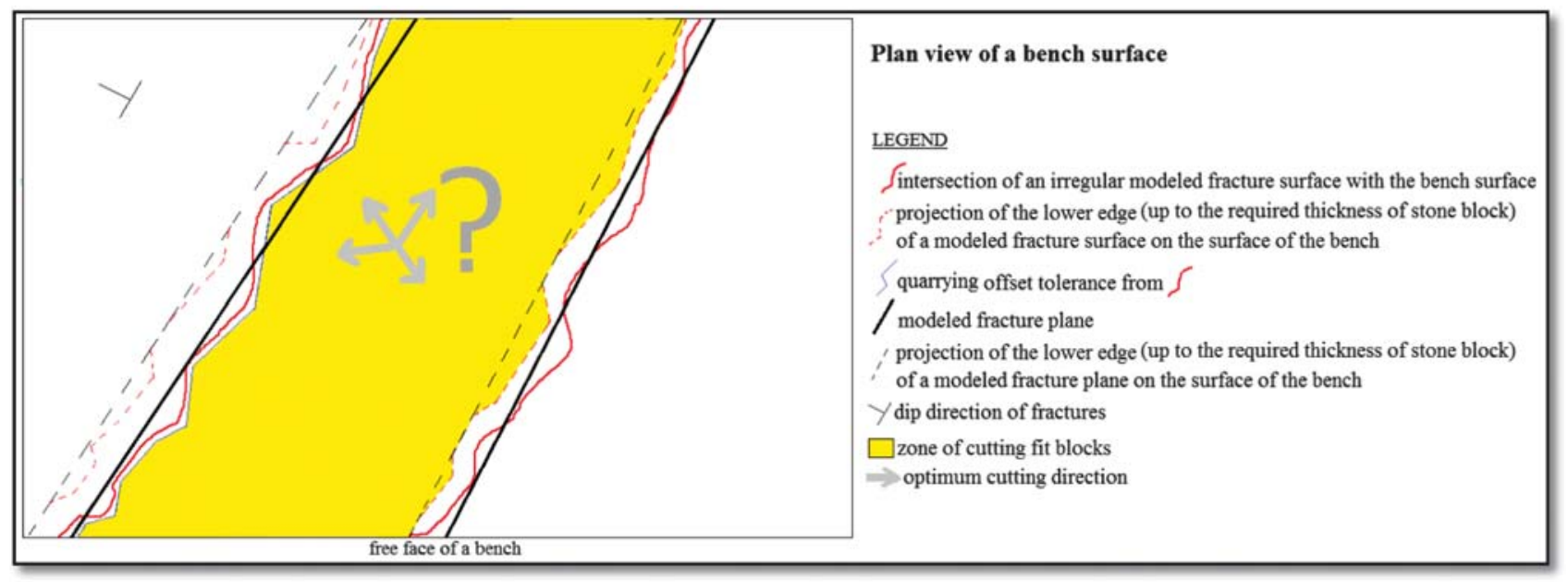

Figure 16: A non-scale hypothetical sketch graphically presents a suggested approach of optimizing the production (minimizing the waste) after accurate modelling of fractures as $3 \mathrm{D}$ surfaces.

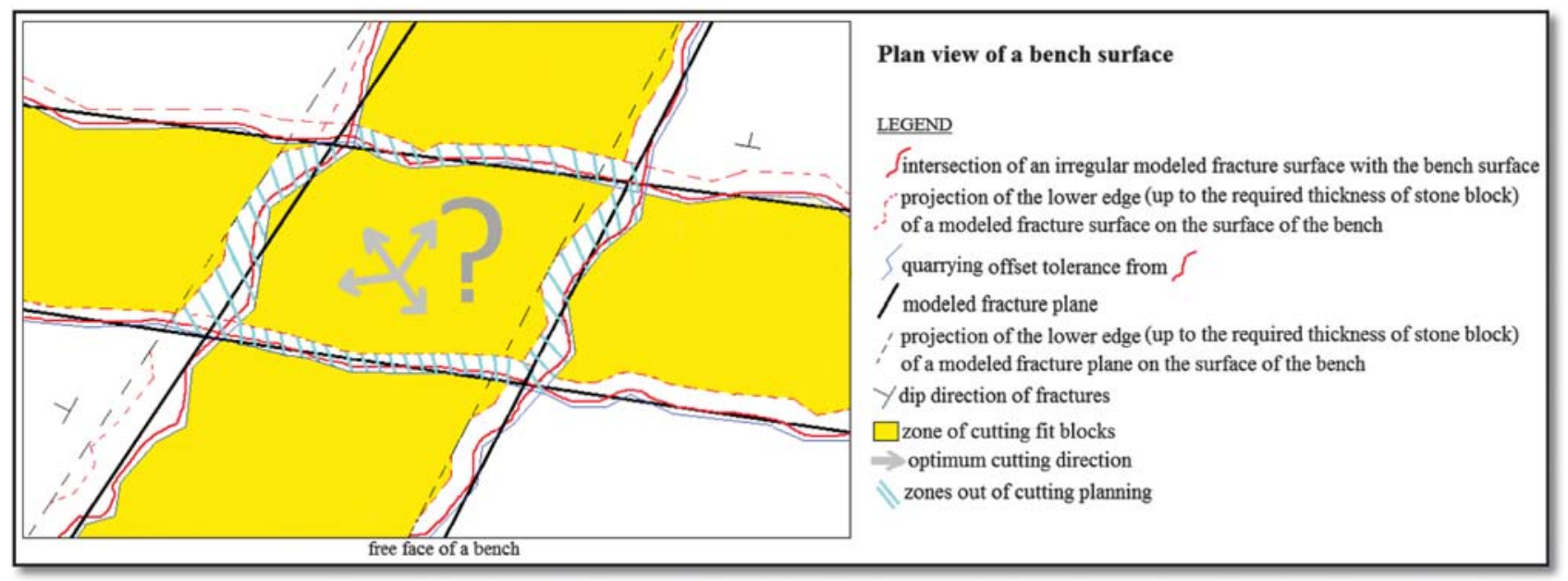

Figure 17: A non-scale hypothetical sketch graphically presents a complex case of two intersected sets of fractures. The hatched zones are zones out of cutting planning because of fractures whilst the free yellow zone is the zone in which finding the optimum cutting direction is required. The hatched zone should be, in any case, cut by any way to continue quarrying the zones of cutting fit blocks.

that the entire body of the commercial quality stratum is different than its outcrop in the bench face in which large aperture fractures are noticeable as compared to another close part of the bench.

\section{Conclusions}

In Case Study 1, the use of a high frequency antenna of $400 \mathrm{MHz}$ to detect fractures in a quarry bench of sandstone led to the accurate detection of fracture traces in successive radargrams. Proper survey planning followed by an interpretation tracing technique allowed for the modelling of the detected sub-vertical fractures as 3D irregular surfaces. Visualization of fracture surfaces through graphical software can assist in exploring the spatial behaviour of fracture surfaces in different orientations.
The out-cropping fractures are not a real indicator to what is inside the rock mass. This was demonstrated by a comparison between mapping the intensity of the outcropping fractures in the bench surface and the results of the GPR survey, particularly in a free-areas of out-cropping fractures. The comparison showed that hidden subhorizontal fractures could be detected in the free-areas of out-cropping fractures in the bench surface.

To maximize the quantity of extracted commercialsize of fit blocks simultaneously with performing a sustainable exploitation by minimizing the waste, a suggested optimization approach based on modelling fractures as 3D surfaces is graphically proposed. With this approach, it was shown that modelling fractures as 3D surfaces can be more promising, in terms of production optimization, than the typical modelling of fractures as planes. This can be done by developing a production op- 
timization model that suggests the optimal cutting direction based on accurate 3D fractures modelling.

Case Study 2 showed the ability of a low frequency GPR antenna of $70 \mathrm{MHz}$ to detect large aperture size of fractures in a quarry bench of sandstone reaching to a penetration depth of $14.0 \mathrm{~m}$. Planning an intensive three dimensional survey grid, with the use of low frequency antenna, is quite important to minimize the effect of the low resolution. The interpolation of the radargrams, using the signal processing software package, led to the creation of a three dimensional GPR model of the rock mass body. The detected large aperture fracture could be investigated through 3D cross-sectional and 3D transparent GPR models. This allowed for the identification of a three-dimensional rock body in the rock mass characterized by the lowest amount of large aperture fractures. However, mechanical rock laboratory tests for rock samples from this bench and using a higher GPR antenna frequency are recommended for future work development.

Using a wide range of GPR frequencies, in application to evaluate fracture status and model fractures in ornamental stone deposit, is recommended to have a compromise between the resolution and penetration depth. However using a wide range of frequencies is time consuming, and currently this issue can be tackled when dual-frequency GPR antenna systems are available.

\section{Acknowledgements}

The authors are grateful to "La Borghigiana" quarrying company of Firenzuola (FI) for allowing the in-situ GPR tests. A special word of thanks goes to EU-METALIC II - ERASMUS MUNDUS program that funds the $\mathrm{PhD}$ scholarship of the lead author of the paper.

\section{References}

Annan, A. P., (2003): Ground penetrating radar principles, procedures, and applications. Sensors \& Software Inc, Mississauga, Canada. (DOI:10.1016/B978-0-444-533487.00016-8)

Annavarapu, S., Kemeny, J., Dessureault, S., (2012): Joint spacing distributions from oriented core data. International Journal of Rock Mechanics and Mining Sciences, 52, 4045. (DOI:10.1016/j.ijrmms.2012.02.003)

Ashmole, I. and Motloung, M., (2008): Dimension stone: The latest trends in exploration and production technology. In: Proceedings of The International Conference on Surface Mining 2008 - Challenges, Technology, Systems and Solutions - Papers. The Southern African Institute of Mining and Metallurgy, Johannesburg, Republic of South Africa, 35-70.

Bargossi, G., Gamberini, F., Gasparotto, G., Grillini, G.C., Marocchi, M., (2004): Dimension and ornamental stones from the Tosco-Romagnolo and Bolognese Apennine. Period. di Mineral., 73 (3), 171-195.

Bargossi, G. M., Gamberini, F., Fabbri, S., Peddis, F., Ravaglia, B., Vescogni, C., Marini, P., Bellopede R., (2008):
Mineralogical-petrographic and physical-mechanical characterization, In: Bartolomei, A. and Montanari, F. (Eds.), Pietra Serena, Materia Della Citta. Edizioni AIDA Firenze (Florence), Italy, 57-84.

Botelho, M. A. B. and Mufti, I. R., (1998): Exploitation of limestone quarries in Brazil with depth migrated groundpenetrating radar data. SEG Technical Program Expanded Abstracts 1998, 836-839. DOI: 10.1190/1.1820616

Bristow, C. S. and Jol, H. M. (eds), (2003): Ground Penetrating Radar in Sediments. Geological Society, London, Special Publications No. 211.

Carreon-Freyre, D. C. and Cerca, M., (2006): Delineating the near-surface geometry of the fracture system affecting the Querétaro valley, Mexico: Correlation of GPR signatures and physical properties of sediments. Near Surface Geophysics, 4 (1), 49-55.

Coli, M., Livi, E., Pandeli, E., Tanini, C., (2012): Pietra Serena mining in Fiesole. PartII: geological situation. Journal of Mining Science, 39 (1), 81-87.

Daniels, D. J., 2004. Ground penetrating radar, second. ed. The Institute of Electrical Engineers, London, UK.

Davis, J. L. and Annan, A. P., 1989. Ground-penetrating radar for high resolution mapping of soil and rock stratigraphy. Geophysical Prospecting, 37, 531-551. (DOI: 10.1111/ j.1365-2478.1989.tb02221.x)

Dezayes, C., Villemin, T., Pêcher, A., (2000): Microfracture pattern compared to core-scale fractures in the borehole of Soultz-sous-Forêts granite, Rhine graben, France. Journal of Structural Geology, 22, 723-733. (DOI:10.1016/S01918141(00)00003-1)

Dorn, C., Linde, N., Le Borgne, T., Bour, O., De Dreuzy, J-R., (2013): Conditioning of stochastic 3-D fracture networks to hydrological and geophysical data. Advances in Water Resources, 62, 79-89. (DOI:10.1016/j.advwatres.2013. 10.005)

Elkarmoty, M., Colla, C., Gabrielli, E., Bonduà, S., Bruno, R., (2016): Application of low frequency GPR antenna to fractures detection and $3 \mathrm{D}$ visualization in a new quarry bench (E-poster), In: The Proceedings of International Conference on Geosciences and Geophysics, 6-7 October 2016, Orlando, USA. Journal of Geology and Geophysics, 5, 5 (suppl), pp. 47. (DOI: 10.4172/2381-8719.C1.006)

Elkarmoty, M., Colla, C., Gabrielli, E., Bonduà, S., Bruno, R., (2017a): A Combination of GPR survey and laboratory rock tests for evaluating an ornamental stone deposit in a quarry bench. Procedia Engineering, 191, 999-1007. (DOI: 10.1016/j.proeng.2017.05.272)

Elkarmoty, M., Colla, C., Gabrielli, E., Papeschi, P., Bonduà, S., Bruno, R., (2017b): In situ GPR test for three dimensional mapping of the dielectric constant in a rock mass. Journal of Applied Geophysics, 146, 1-15. (DOI:10.1016/j. jappgeo.2017.08.010)

Elkarmoty, M., Colla, C., Gabrielli, E., Bonduà, S., Bruno, R., (2017c): Deterministic three-dimensional rock mass fracture modelling from geo-radar survey: A case study in a sandstone quarry in Italy. Environmental and Engineering Geoscience, early publication version, published on 22 March 2017, in press article. (DOI:10.2113/EEG-1900) 
Ferrero, A. M., Forlani, G., Roncella, R., Voyat, H. I., (2009): Advanced geostructural survey methods applied to rock mass characterization. Rock Mechanics and Rock Engineering, 42, 631-665. (DOI:10.1007/s00603-008-0010-4)

Galić, I., Vidić D., Jembrich, Ž., (2011): The influence of The coefficient of utilization of reservoir feasibility of dimension stone production and improvement opportunities. Rudarsko-geološko-naftni Zbornik, 15, 117-130.

Haeni, F. P., Halleux, L., Johnson, C. D., Lane, J. W., (2002): Detection and mapping of fractures and cavities using borehole radar borehole radar, In: The proceedings of Fractured Rock 2002. 13-15 March 2002, Denver, Colorado, USA. Proceedings: Westerville, Ohio, National Ground Water Association, 4p.

International Society of Rock Mechanics [ISRM], (1979): Suggested methods for the quantitative description of discontinuities in rock masses. International Journal of Rock Mechanics and Mining Sciences \& Geomechanics Abstracts, 15 (6), 319-368. (DOI: 10.1016/0148-9062 (78)91472-9)

Jeannin, M., Garambois, S., Grégoire, C., Jongmans, D., (2006): Multiconfiguration GPR measurements for geometric fracture characterization in limestone cliffs (Alps). Geophysics, 71(3), 85-92. (DOI:10.1190/1.2194526)

Kadioglu, S., (2008): Photographing layer thicknesses and discontinuities in a marble quarry with 3D GPR visualisation. Journal of Applied Geophysics, 64, 109-114. (DOI: 10.1016/j.jappgeo.2008.01.001)

La Borghigiana Srl Website, (2017): URL www.laborghigiana. com/gamma/ (accessed $21^{\text {st }}$ Januarary 2017)

Lato, M. J. and Vöge, M., (2012): Automated mapping of rock discontinuities in 3D lidar and photogrammetry models. International Journal of Rock Mechanics and Mining Sciences, 54, 150-158. (DOI:10.1016/j.ijrmms.2012.06.003)

Lau, J. S. O., Auger, L. F., Bisson, J. G., (1987): Subsurface fracture surveys using a borehole television camera and acoustic televiewer. Canadian Geotechnical Journal, 24 (4), 499-508.

Lu, P. and Latham, J. -P., (1999): Developments in the assessment of in-situ block size distributions of rock masses. Rock Mechanics and Rock Engineering, 32 (1), 29-49. (DOI:10.1007/s006030050042)

Luodes, H. and Sutinen, H., (2011): Evaluation and modelling of natural stone rock quality using Ground Penetrating Radar (GPR), In: Nenonen, K., Nurmi P. A. (Eds.), Geoscience for Society, $125^{\text {th }}$ Anniversary Volume. Geological Survey of Finland, Special Paper 49. 83-90.

Mineo, S., Pappalardo, G., Rapisarda, F., Cubito, A., Di Maria, G., (2015): Integrated geostructural, seismic and infrared thermography surveys for the study of an unstable rock slope in the Peloritani Chain (NE Sicily). Engineering Geology, 195, 225-235. (DOI:10.1016/j.enggeo.2015.06.010)

Mosch, S., Nikolayew, D., Ewiak, O., Siegesmund, S., (2011): Optimized extraction of dimension stone blocks. Environmental Earth Sciences, 63 (7), 1911-1924. (DOI:10.1007/ s12665-010-0825-7)

Mysaiah, D., Maheswari, K., Srihari Rao, M., Senthil Kumar, P., Seshunarayana, T., (2011): Ground-penetrating radar applied to imaging sheet joints in granite bedrock. Current Science, 100 (4), 473-475.

Olariu, M. I., Ferguson, J. F., Aiken, C. L. V., Xu, X., (2008): Outcrop fracture characterization using terrestrial laser scanners: Deep-water Jackfork sandstone at big rock quarry, Arkansas. Geosphere, 4 (1), 247-259. (DOI:10.1130/ GES00139.1)

Paraview Website, (2017): URL: http://www.paraview.org/ (accessed $1^{\text {st }}$ Januarary 2017)

Pipan, M., Baradello, L., Forte, E., Prizzon, A., (2000): GPR study of bedding planes, fractures and cavities in limestone, In: Noon, D. A., Stickley, G. F., Longstaff, D. (Eds.), The Proceedings of the 8th International Conference on Ground Penetrating Radar., 23 May 2000, Gold Coast, Australia., 682-687. (DOI:10.1117/12.383499)

Report of United Nations, 1976. The development potential of dimension stone. Department of Economic and Social Affairs, New York, USA.

Reynolds, J. M., (2011): An introduction to applied and environmental geophysics, second. ed. A John Wiley \& Sons, Ltd., West Sussex, UK.

Seren, A. and Acikgoz, A. D., (2012): Imaging fractures in a massive limestone with ground penetrating radar, Haymana, Turkey. Scientific Research and Essays, 7 (40), 33683381. (DOI:10.5897/SRE11.1877)

Serzu, M. H., Kozak, E. T., Lodha, G. S., Everitt, R. A., Woodcock, D. R., (2004): Use of borehole radar techniques to characterize fractured granitic bedrock at AECL's Underground Research Laboratory. Journal of Applied Geophysics, 55, 137-150. (DOI:10.1016/j.jappgeo.2003.06.012)

Slob, S., Hack, H. R. G. K., Feng, Q., Röshoff, K., Turner, A. K., (2007): Fracture mapping using 3D laser scanning techniques. In: Ribeiro E Sousa, L., Olalla, C., Grossmann, N. F. (Eds.), The Proceedings of the $11^{\text {th }}$ Congress of the International Society for Rock Mechanics; The second half century of rock mechanics, Lisbon, Portugal, 9-13 July 2007. Taylor \& Francis; Balkema, Leiden, The Netherlands, 299-302.

Theune, U., Rokosh, D., Sacchi, M. D., Schmitt, D. R., (2006): Mapping fractures with GPR: A case study from Turtle Mountain. Geophysics, 71(5), 139-150. (DOI:10.1190/ $1.2335515)$

Vasuki, Y., Holden, E-J., Kovesi, P., Micklethwaite, S., (2014): Semi-automatic mapping of geological Structures using UAV-based photogrammetric data: An image analysis approach. Computers \& Geosciences, 69, 22-32. (DOI: 10.1016/j.cageo.2014.04.012)

Vidić, D., Galić, I., Farkaš, B., (2012): The profitability of dimension stone deposit exploitation in relation to the coefficient of utilization. Mining-Geology-Petroleum Engineering Bulletin, 25, 123-130.

Wackernagel, H., (2003): Multivariate geostatistics: An introduction with applications, third. ed. Springer-Verlag Berlin Heidelberg.

White, C. D., Willis, B. J., Dutton, S. P., Bhattacharya, J. P., Narayanan, K., (2004): Sedimentology, statistics, and flow 
behavior for a tide-influenced deltaic sandstone, Frontier Formation, Wyoming, United States, In: Grammer, G. M., Harris, P. M., Eberli, G. P. (Eds.), Integration of Outcrop and Modern Analogs in Reservoir Modelling: AAPG Memoir 80. The American Association of Petroleum Geologists, Tulsa, Oklahoma, 129-152.

Zajc, M., Pogačnik, Ž., Gosar, A., (2014): Ground penetrating radar and structural geological mapping investigation of karst and tectonic features in flyschoid rocks as geological hazard for exploitation. International Journal of Rock Mechanics and Mining Sciences, 67, 78-87. (DOI:10.1016/j. ijrmms.2014.01.011)

Zou, D. H. and Wu, Y. K., (2001): Investigation of blast-induced fracture in rock mass using reversed vertical seismic profiling. Journal of Applied Geophysics, 48 (3), 153-162. (DOI:10.1016/S0926-9851(01)00079-9)

\section{SAŽETAK}

\section{Kartiranje i modeliranje pukotina iz podataka dobivenih zemaljskim radarom u procjeni kvalitete ukrasnoga kamena i optimiziranju pridobivanja (dva primjera)}

Stijenska masa obično je obilježena pukotinama koje uzrokuju prirodno komadanje kamena. Rezanje blokova u takvim kamenolomima može prouzročiti preveliki udio „otpada” (nekorisne stijenske mase) ili pridobivanje raspucanih blokova. Prikazana su dva slučaja istražena uporabom niskofrekvencijskoga i visokofrekvencijskoga zemaljskoga prodirućeg radara (skr. ZPR), kojim su zabilježene pukotine u dvama dijelovima kamenoloma. U prvome slučaju snimanje visokim frekvencijama rabljeno je za: (i) usporedbu radarskih rezultata interpoliranih običnim krigiranjem, s kartom fraktura opaženih na površini stijenskoga ureza, te (ii) prikaz načina modeliranja približno okomitih pukotina u tri dimenzije, a na temelju radarskih mjerenja. Drugi slučaj temeljio se na uporabi niskih frekvencija, kojima su opažane pukotine većih promjera te praćene što dublje u kameni blok s ciljem određivanja dubine jedre stijene prije vađenja. To je načinjeno izučavanjem trodimenzionalnoga radarskog modela profila i transparentnosti. Na kraju je prikazan teorijski model planiranja pridobivanja koji je uključio trodimenzionalni prikaz pukotina, a s ciljem optimiziranja i/ili povećanja proizvodnje. Uporaba radara pokazala su korisnim alatom za procjenu ležišta ukrasnoga kamena, odnosno optimizaciju njegova pridobivanja.

\section{Ključne riječi:}

zemaljski prodirući radar, model pukotina, ukrasni kamen, planiranje vađenja kamena

\section{Author(s) contribution}

This paper is from the PhD research of the first author: Mohamed Elkarmoty, who participated in the GPR survey, processed and analysed the GPR data, developed the fracture model, proposed a quarrying optimization approach in addition to writing the first draft of the paper. Camilla Colla and Elena Gabrielli contributed in planning and performing of the GPR survey. The supervisors of the PhD thesis of Mohamed Elkarmoty (Stefano Bonduà and Roberto Bruno) technically improved and supervised the work of Mohamed particularly in the fracture modeling, data analysis and in the quarrying part. The Geo-statistical work in this paper was performed by Francesco Tinti and Sara Kasmaeeyazdi who contributed in writing this part of the paper. 